\title{
MODELING THE IMPACT OF DIVERSIFICATION OF IMPORTS ON THE NATURAL GAS MARKET OF UKRAINE
}

\author{
Vladyslav Ramazanov, PhD student in Economical Sciences, \\ National University «Yuri Kondratyuk Poltava Polytechnic», \\ Head of expert group on security of supply and development of competitive natural gas \\ market of Directorate of Oil and Gas Complex and Oil, Natural Gas and Petroleum Products \\ Marker Development, \\ Ministry of Energy of Ukraine
}

(C) Ramazanov V., 2020.

Стаття отримана редакиією 19.11.2020 p.

The article was received by editorial board on 19.11.2020

Introduction. Diversification is a broad concept that provides for an even distribution of risks in order to reduce their negative potential impact.

Diversification can concern types of energy resources, sources of energy resources, types of energy technologies. It is believed, that diversification of energy supply by type and origin provides a higher level of energy security. However, diversification alone does not lead to a positive impact on energy security if it concerns the use of additional less reliable energy sources [12; 14].

Key drivers' forces and instruments of EU energy security are the completion of construction internal integrated energy market, diversification of sources supply of energy resources, strengthening cooperation between states on transportation and storage of natural gas, increase energy efficiency, reduction of harmful emissions into the atmosphere [15].

The economic modeling is the reproduction of economic objects and processes in limited, small, experimental forms, in artificial conditions. Modeling is a prerequisite and a means of analyzing the economy and the phenomena occurring in it, and substantiation of decisions, forecasting, planning, management of economic processes and facilities. In this case, the model means the reflection of the real economic situation, the process in the form of a scheme, algorithm or in some other way. The encyclopedic dictionary gives the following definition of this concept: economic model - a simplified representation of reality, abstract generalization, embodied in the form of economic and mathematical model [13].

Based on the study, it can be argued, that Ukraine considers its own energy security in the context of strengthening cooperation with the EU in the field of energy. Ukraine seeks to implement or expand projects to diversify natural gas supplies, strengthen its status as a reliable transit country, and integrate into the EU's energy space.

As part of a targeted policy to diversify natural gas sources, Ukraine is cooperating with European operators of related gas transmission systems on the possibility of signing a «cooperation agreement» at all connection points, as well as providing and expanding technical capabilities for gas transportation from Europe.

Significant capacity of gas storage facilities in Ukraine in this case can be used for seasonal price arbitrage to reduce the total cost of imported gas.

Basic material and results. Based on the proposed conceptual and methodological approach to assessing the level of diversification of the natural gas market of Ukraine, a model of diversification of the natural gas market has been developed, which is based on the following indicators.

Partial indicators of diversification, which reflect the external aspects of the EU natural gas market, include: dependence on natural gas imports; the number of entry points into the gas transmission system of Ukraine for the import of natural gas (the number of external sources and routes for the supply of natural gas); number of natural gas suppliers; quantity and specific weight of components of the complex of primary gaseous energy carriers imported (natural gas, liquefied gas, shale gas and biogas).

It is known that the state's dependence on the natural gas port is one of the most important indicators in terms of energy security. This indicator is usually determined by the ratio of total imports of natural gas to 
total consumption of this energy for a certain period of time, and countries, depending on this indicator in percentage are classified into the following groups $[1-2,8]$ :

- countries with low dependence on imports $(\leq 10 \%)$ and countries-exporters;

- countries with average dependence on imports (30\% - 40\%);

- countries with high dependence on imports $(\geq 70 \%)$.

The greater the value of this indicator, the lower the level of diversification of routes and sources of natural gas supply.

According to world standards, the import of natural gas is considered reliable, if the supply is made from at least three sources [6], then if this condition is met, gas supply is diversified.

Maximum supply from one source. Since according to international energy security criteria, the supply of energy resources from one source should not exceed 25\% [3], the maximum supply will be:

$$
Q_{2}=0,25 * Q_{3}
$$

where Q3 - total imports of natural gas, thousand cubic meters.

Relative supply diversification ratio (diversification ratio), which takes into account the number of suppliers and supply volumes.

$$
K_{\partial}=\frac{\sum_{i=1}^{n} Q_{i}}{Q_{3}} * 100 \%,
$$

where $\mathrm{Q}_{\mathrm{i}}$ - the volume of gas supplied by a separate producer (from a separate source), provided that $\mathrm{Q}_{\mathrm{i}} \leq \mathrm{Q}_{\Gamma}$; if $\mathrm{Q}_{\mathrm{i}}>\mathrm{Q}_{\mathrm{r}}$, then in formula (2) $\mathrm{Q}_{\mathrm{i}}$ is taken equal to $\mathrm{Q}_{\mathrm{r}}$; $\mathrm{n}$ is the number of gas supply sources [5].

At present, despite the relatively high cost of liquefaction/regasification technologies and equipment, liquefied natural gas (LNG) supply is a cost-effective alternative to long-distance pipeline transportation of natural gas.

To reduce its dependence on gas imports from Russia, Poland, for example, is expanding LNG purchases in Qatar and the United States. In November 2018, PGNiG agreed with the American Cheniere Marketing International to supply LNG for the next 24 years.

Recently, Poland has signed agreements with US companies to purchase about 6 billion cubic $m$ of LNG totaling about \$ 25 billion and the American Cheniere Energy has started the implementation of this long-term contract for the supply of LNG (according to the document in 2019-2022, the volume of supplies will be about 0.52 million tons of LNG ( 0.73 billion cubic $\mathrm{m}$ of gas after regasification); in 2023-2042 the total volume of LNG imports will reach 29 mln tons (about 39 billion cubic m) since 2023. Paging will receive about 1.45 million tons/year of LNG (about 1.95 billion cubic m). Total shipments will amount to 29.5 million tons of LNG (about 39 billion cubic meters) under this contract, Paging will receive LNG produced in factories Sabine Pass in Louisiana and Corpus Christi, Texas deliveries will be made by the formula DES (delivery ex ship) Incoterms - the seller bears all costs and risks of LNG delivery to the port of destination until it is unloaded at the LNG terminal).

In order to increase the level of energy security of the state, ensure diversification of sources and routes of natural gas supply to Ukraine, integration of the natural gas market of Ukraine into the Energy Community market, work is underway on the project «Construction of Ukraine-Poland gas pipeline interconnector».

The project of building a gas pipeline-interconnector Poland-Ukraine is important for the infrastructure of both Ukraine and Poland. This project is seen as a key project for diversifying natural gas supply sources and routes, security of supply, and creating a fully integrated and competitive regional gas market in Central and Eastern Europe. The project will also help strengthen cooperation between the EU and the Energy Union. The construction of the gas pipeline-interconnector will increase the volume of gas transportation to Ukraine on a permanent basis.

Also, the integration of Polish and Ukrainian gas transmission systems is part of the North-South gas corridor, which allows gas to be transported from the LNG terminal to Swinoujscie via Central and Eastern Europe using cross-border interconnectors. The main goal is to create a flexible transportation infrastructure in Central and Eastern Europe that will connect the Western gas markets and the global LNG market with the Central and Eastern European market. Such a large-scale effect should have a positive effect on competition and the attractiveness of the region in the perspective of market participants. 
The project envisages the integration of gas transmission systems of both countries to increase gas imports to Ukraine from Europe via Poland, as well as to ensure the storage of European gas in storage. On June 13, 2017, after a year of joint work with Naftogaz of Ukraine, the Ministry of Finance and the Energy Customs of the State Fiscal Service, JSC Ukrtransgaz opened a customs warehouse for temporary storage of natural gas in Ukrainian underground storage facilities for the opening and operation of customs warehouses on the basis of Ukrainian gas storage facilities).

The fact of starting to use the «customs warehouse» service is an element of implementing Ukrtransgaz's development strategy as a full-fledged European operator, which is well oriented to the needs of market participants and, accordingly, introduces new services to expand the range of potential customers. The launch of a new mode of operation of gas storage facilities «customs warehouse» is also another step towards the creation of a regional gas hub based on gas storage facilities in Ukraine.

Previously, customs clearance of natural gas transported to the customs territory of Ukraine for its storage in gas storage facilities could be carried out only in the customs regime of «transit». Also, the provisions of the Customs Code of Ukraine set the terms of transit transportation by pipeline - 31 days. Such conditions were not economically acceptable for most foreign gas traders. From now on, customs clearance of gas coming from abroad for storage in Ukrainian gas storage facilities is carried out in the «customs warehouse» mode.

The creation of such a warehouse allows companies, including foreign ones, to store gas on the territory of Ukraine for 1095 days without paying any taxes and customs duties, subject to further transportation of natural gas from the territory of Ukraine. Thus, the Ukrainian legislation removes all legal barriers to the provision of natural gas storage services to non-residents in gas storage facilities.

Ukraine is implementing a European approach and has allocated the GTS operator to an independent structure. The new GTS operator gained independence not only from the current owner, Naftogaz of Ukraine, but also from any other influences from producers and suppliers of natural gas and electricity, in particular through the vertical of public authorities.

An important component of the functioning of the gas transmission system is a complex of natural gas storage facilities, which provides overlapping of peak periods of natural gas consumption in the autumnwinter period.

Table 1 shows the data on the availability of natural gas in the gas storage facilities of JSC Ukrtransgaz at the beginning and end of the selection seasons 2016-2017, 2018-2019.

Availability of natural gas in JSC Ukrtransgaz (billion cubic meters)

\begin{tabular}{|c|c|c|c|c|c|}
\hline \multicolumn{2}{|c|}{$\mathbf{2 0 1 6 - 2 0 1 7}$} & \multicolumn{2}{|c|}{$\mathbf{2 0 1 7 - 2 0 1 8}$} & \multicolumn{2}{|c|}{ 2018-2019 } \\
\hline $\begin{array}{c}\text { At the } \\
\text { beginning of } \\
\text { the selection } \\
\text { season }\end{array}$ & $\begin{array}{c}\text { At the end of } \\
\text { the selection } \\
\text { season }\end{array}$ & $\begin{array}{c}\text { At the } \\
\text { beginning of } \\
\text { the selection } \\
\text { season }\end{array}$ & $\begin{array}{c}\text { At the end of the } \\
\text { selection season }\end{array}$ & $\begin{array}{c}\text { At the } \\
\text { beginning of } \\
\text { the selection } \\
\text { season }\end{array}$ & $\begin{array}{c}\text { Finally } \\
\text { season } \\
\text { selection }\end{array}$ \\
\hline 14.7 & 8.1 & 17.0 & 7.4 & 17.2 & 8.7 \\
\hline
\end{tabular}

Source: data of NJSC «Naftogaz of Ukraine»

Table 2 shows the data on the actual recorded maximum daily gas extraction from gas storage facilities and the average daily gas extraction from gas storage facilities during the season.

Volumes of the level of gas extraction from gas storage facilities (million cubic meters)

\begin{tabular}{|c|c|c|c|c|c|}
\hline \multicolumn{2}{|c|}{ 2016-2017 } & \multicolumn{2}{c|}{ 2017-2018 } & \multicolumn{2}{c|}{ 2018-2019 } \\
\hline $\begin{array}{c}\text { Maximum } \\
\text { daily selection }\end{array}$ & $\begin{array}{c}\text { Average daily } \\
\text { selection }\end{array}$ & $\begin{array}{c}\text { Maximum } \\
\text { daily selection }\end{array}$ & $\begin{array}{c}\text { Average daily } \\
\text { selection }\end{array}$ & $\begin{array}{c}\text { Maximum } \\
\text { daily selection }\end{array}$ & $\begin{array}{c}\text { Average daily } \\
\text { selection }\end{array}$ \\
\hline 91.9 & 41.0 & 116.3 & 57.1 & 101.2 & 55,2 \\
\hline
\end{tabular}

Source: data of NJSC «Naftogaz of Ukraine»

As part of modeling the impact of import diversification on the natural gas market of Ukraine, it is worth noting that Ukraine is interested in participating in the Southern Gas Corridor project. The specific format of such participation is a matter for detailed study and discussion at the level of experts of the Ministries of Energy of our countries. 
For reference: The Southern Gas Corridor consists of three pipelines SCPX (South Caucasus Pipeline Expansion), TANAP (Trans Anatolian Pipeline) and TAP (Trans Adriatic Pipeline) and is designed to transport gas from the gas fields of Azerbaijan to European consumers. The first stage of the PGC project envisages the transportation of 16 billion cubic m of natural gas to Europe from 2020 with the possibility of increasing these volumes to 24 billion cubic $m$ in 2023 and 31 billion cubic $m$ in 2026. Currently, the consortium «Shah Deniz» signed long-term agreements for the supply of natural gas to Turkey (6 billion cubic m per year), Italy (9 billion cubic m per year) and Bulgaria (1 billion cubic m per year), Fig.1.

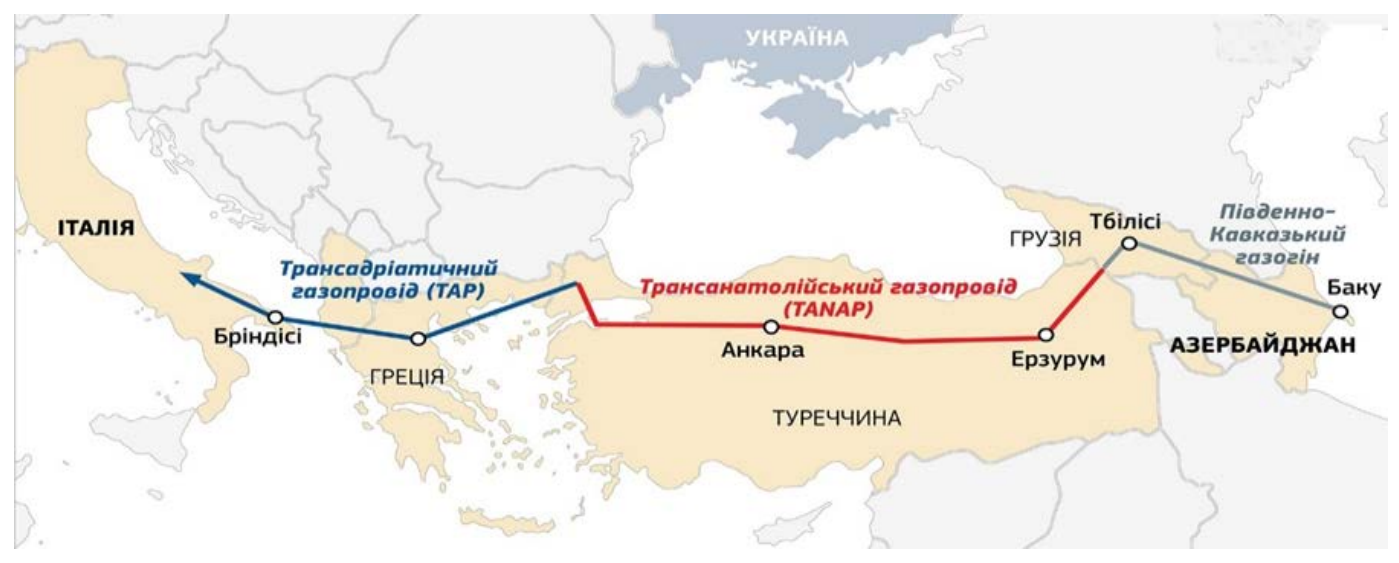

Fig. 1. Trans-Anatolian gas pipeline

Given the above, it would be appropriate to use the existing potential of natural gas storage facilities in Western Ukraine, which can provide storage of natural gas to be transported under the PGC project. This option does not require additional investment in the installation of new gas storage facilities along the PGK pipelines and will help ensure an uninterrupted supply of natural gas to consumers, especially during the winter.

In the study, Ukraine's dependence on natural gas imports is expressed by a dimensionless indicator equal to the ratio of the total volume of natural gas imported by Ukraine to the total annual consumption of natural gas in Ukraine:

$$
X \text { imports }=(Y \text { imports }) /(Y \text { consumption })
$$

where

$\mathrm{X}$ imports - a dimensionless indicator of dependence on natural gas imports;

$\mathrm{Y}$ imports - total annual imports of natural gas;

Y consumption - total natural gas consumption per year.

The dimension lessens of this indicator is ensured by the fact that the total volume imports of natural gas per year and the total consumption of natural gas per year, which are used for its calculation, have the same units of measurement. The greater the value of this indicator the greater the level of dependence on natural gas imports.

One of the most important indicators of natural gas market diversification is the number and type of entry points for natural gas imports (number and type of external sources of supply), which should be diversified geographically or by natural gas supplier countries.

In this case, natural gas can be imported through LNG infrastructure, including FSRU platforms (floating storage and regasification units), or through pipelines. Gas pipelines - interconnectors and gas hubs can also be used for this purpose. The more entry points a state has, the less vulnerable it is to gas supply disruptions.

The national project «LNG Terminal» provides for the construction of an LNG terminal for the reception, storage and regasification of liquefied natural gas in the waters of the seaport «South» Kominternovskyi district of Odesa region with a capacity of 10 billion cubic m/year. 


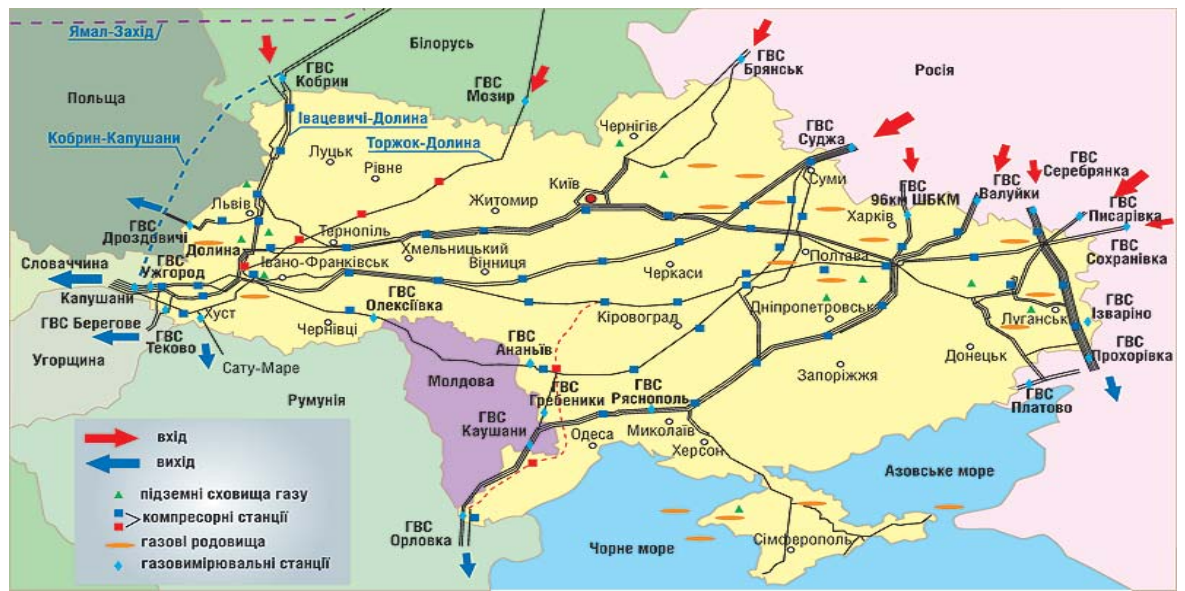

Fig. 2 point and input-output in Ukraine's GTS

The ports are equipped with LNG infrastructure facilities may provide greater external stability of the power system state than pipelines, because through them, the gas can be imported on short-term contracts because of the spot LNG market, while by pipeline gas usually imported under long-term contracts from predefined suppliers [9].

Diversification of energy sources and supply routes is one of the most important elements of ethical security. It is considered that the supply of energy for import is safe if it is carried out from at least three sources [4].

Conclusions. The analysis of alternative ways of natural gas transportation to Ukraine and their diversification allowed to formulate the following conclusions:

1. In the process of determining the price of natural gas, the methods of its transportation play a very important role. Recently, gas prices in Europe have approached the level that makes LNG competitive in European gas markets. These facts are very interesting for Ukraine. It is determined that, despite the advantages of gas pipeline transport, pipelines are impractical for long-distance sea transportation of gas.

2. Currently, for the purpose of long-distance sea/ocean transportation of gas using liquefaction technologies LNG - tankers (gas carriers). The national project «LNG Ukraine» provides for the construction of an LNG terminal for the supply, storage and regasification of liquefied natural gas in the waters of the seaport «South» Kominternovskyi district of Odesa region. Analysis of the implementation strategy of the national project «LNG Ukraine» and financial and economic indicators of the project led to the conclusion that the implementation of the national project «LNG Ukraine - the creation of infrastructure for liquefied gas to Ukraine» is cost-effective and feasible for Ukraine.

3. The technical and economic feasibility of the project «LNG - resource» (part of the national project «LNG Ukraine» - to create an infrastructure for liquefied natural gas in Ukraine), features of the production cycle and trade of LNG, factors of its competitiveness and business models of project financing national project «LNG Ukraine - the creation of infrastructure for liquefied natural gas in Ukraine». Thus, the analysis of international experience has shown that compliance with the principle of diversification of energy sources and routes is recognized as a decisive factor in security of supply and ensuring the economic independence of Ukraine. The results of the study allowed us to conclude that Ukraine needs to achieve a certain level of diversification by working to increase the number of gas sources to the three minimum necessary, for example, by transporting liquefied gas.

\section{REFERENCES:}

1. Badea A.C. Energy Security Indicators. European Commission Joint Research Center Institute for Energy Security Unit, available at: http://www.drustvo-termicara.com/resources/files/7fa5460.pdf

2. Bolado - Lavin, R., Gracceva, F., Zeniewski, P. et al. (2012). Best practices and methodological guidelines for conducting gas risk assessments. Luxembourg: Publications Office of the European Union. 104 p., available

at: https://ec.europa.eu/energy/sites/ener/files/documents/jrc68735_best_practices_and_methodological_guideli nes for conducting gas risk assessments.pdf

3. Volovych A. "Prospects diversification of sources of supply of energy in Ukraine". National Institute for Strategic Studies, available at: http //www.niss.gov.ua/ monitor/mart2009/5.html 
4. Dziadykevych Yu.V. (2014). Energy security of Ukraine and its components. Innovative economy [Online]. No 6. P. 5-13, available at: http://nbuv.gov.ua/UJRN/inek_2014_6_2

5. Dzob, O.H., Romashko, O.M. (2012), Estimation of the level of diversification of natural gas supply in the countries of the European Union. Economic Journal -XXI, No 7-8, P. 37-40.

6. Razumkov, O. (2009). Ukrainian Center for Economic and Political Studies «Diversification projects in the energy sector of Ukraine: state, problems and ways of their implementation». National Security and Defense, No 6, P. 2-53.

7. The Verkhovna Rada of Ukraine (2015). Law of Ukraine "On the market of natural gas”, available at: http://zakon5.rada.gov.ua/laws/show/329-19

8. Jewell, J. (2011). The IEA Model of Short-Term Energy Security. International Energy Agency, 43 p., available at: https://www.iea.org/publications/freepublications/publication/moses paper.pdf

9. Muzychenko, M.V. (2018), "The differentiation of the EU natural gas market in the context of energy security". Abstract of Ph.D. dissertation, World economy and the international economic relations, V.N. Karazin Kharkiv National University, Kharkiv, Ukraine.

10. Preliminary feasibility study of the project "LNG terminal" - offshore LNG terminal developed by the Spanish company "SOCOIN", 2012

11. Decree of the Cabinet of Ministers of Ukraine of August 8, 2012 № 603-p, [Online], available at: https://zakon.rada.gov.ua/laws/show/603-2012-\%D1\%80

12. Tucci, P.A. (2014). “The handy investing answer book”. Detroit: Visible Ink Press, 384 p. [Online], available at: https://academlib.com/14520/business_finance / portfolio \# 668

13. Chikhrai, V., Popova, A.S. Building an economic model of the process of creating an enterprise information system. Odessa National Academy of Communication [Online], available at: http://www.rusnauka.com/7 NND 2009/Economics/43098.doc.htm

14. Van der Linde, C. Amineh, M.P., Correlje, A. et al. (2004). "Study Energy Supply Security and Geopolitics”. Clingendael International Program (CIEP). Hague: The Netherlands Institute of International Relations, 281 p. [Online], available at:

http://www.clingendaelenergy.com/inc/upload/files/Study on energy supply security and geopolitics.pdf

15. Muzychenko, M.V. (2018) "Diversification of the EU natural gas market in the context of energy security”. Ph.D. Thesis, World economy and the international economic relations, V.N. Karazin Kharkiv National University, Kharkiv, Ukraine.

УДК 339.562:339.13.024

JEL C59, E37, F17, L71

Рамазанов Владислав Андрійович, аспірант. Національний університет «Полтавська політехніка імені Юрія Кондратюка». Моделювання впливу диверсифікації імпорту на ринок природного газу України. Запропоновано інструментарій кількісного оцінювання рівня диверсифікації імпортних джерел та маршрутів постачання природного газу, здійснено оцінку рівня диверсифікації газового ринку України, визначено пріоритетні шляхи підвищення рівня диверсифікації ринку природного газу України в контексті інтеграції до ринку природного газу ЄС. На основі запропонованого концептуально-методичного підходу до оцінювання рівня диверсифікації ринку природного газу України розроблено модель диверсифікації ринку природного газу нашої держави.

Енергетична безпека - це своєчасне, повне і безперебійне забезпечення паливом та енергією необхідної якості матеріального виробництва, невиробничої сфери, населення, комунальнопобутових й інших споживачів; запобігання шкідливому впливу на довкілля; транспортування, перетворення і споживання паливно-енергетичних ресурсів в умовах сучасних ринкових відносин, тенденцій та показників світового ринку енергоносіїв. Власну енергетичну безпеку Україна розглядає у контексті посилення співробітництва з СС у сфері енергетики. Вона прагне реалізувати або розширити проекти 3 диверсифікації постачання природного газу, зміцнити свій статус надійної транзитної країни, інтегруватися в енергетичний простір СС. У рамках цілеспрямованої політики на диверсифікацію джерел надходження природного газу Україна співпрацює 3 європейськими операторами суміжних газотранспортних систем щодо можливості підписання по всіх точках з'єднання «угоди про взаємодію», а також працює над забезпеченням і розширенням технічних можливостей транспортування газу з території країн Європи. Значні потужності газосховищ в Україні 
в цьому разі можуть використовуватися для сезонного арбітражу цін для зниження загальної вартості імпортного газу.

Ключові слова: оцінювання, ефективність механізму, реверсне постачання газу, контракт, транспортування природного газу, енергетична незалежність, економіка.

UDC 339.562:339.13.024

JEL C59, E37, F17, L71

Vladyslav Ramazanov, PhD student in Economical Sciences. National University «Yuri Kondratyuk Poltava Polytechnic». Modeling the Impact of Diversification of Imports on the Natural Gas Market of Ukraine. The tools of quantitative assessment of the level of diversification of imported sources and routes of natural gas supply are proposed, the level of diversification of the gas market of Ukraine is assessed, priority ways to increase the level of diversification of the natural gas market of Ukraine in the context of integration into the EU natural gas market are identified. Based on the proposed conceptual and methodological approach to assessing the level of diversification of the natural gas market of Ukraine, a model of diversification of the natural gas market of our country has been developed.

Energy security is a timely, complete and uninterrupted supply of fuel and energy of the required quality of material production, non-productive sphere, population, utilities and other consumers; prevention of harmful effects on the environment; transportation, transformation and consumption of fuel and energy resources in the conditions of modern market relations, tendencies and indicators of the world energy market. Ukraine considers own energy security in the context of enhanced cooperation with the EU in the energy sector. Ukraine seeks to implement or expand projects to diversify natural gas supplies, strengthen its status as a reliable transit country, and integrate into the EU's energy space. As part of a targeted policy to diversify natural gas sources, Ukraine cooperates with European operators of related gas transmission systems on the possibility of signing a «cooperation agreement» at all connection points, as well as providing and expanding technical capabilities for gas transportation from Europe. Significant capacity of gas storage facilities in Ukraine in this case can be used for seasonal price arbitrage to reduce the total cost of imported gas.

Key words: evaluation, mechanism efficiency, reverse gas supply, contract, natural gas transportation, energy independence, economy. 